\title{
Perovzalates: a family of perovskite-related oxalates
}

Rebecca Clulow ${ }^{1}$, Alasdair Bradford ${ }^{1,2}$, Stephen L. Lee ${ }^{2}$ and Philip Lightfoot ${ }^{1 *}$

1. School of Chemistry and EaStChem, University of St Andrews, St Andrews, Fife, KY16 9ST, UK

2. School of Physics, University of St Andrews, St Andrews, Fife, KY16 9SS, UK

*E-mail: pl@st-andrews.ac.uk

\begin{abstract}
A family of hybrid Perovskite-oxalates ("Perovzalates") of general composition $A^{\prime} \mathrm{Li}_{3} \mathrm{M}^{\prime \prime}\left(\mathrm{C}_{2} \mathrm{O}_{4}\right)_{3}\left(\mathrm{~A}=\mathrm{K}^{+}\right.$, $\mathrm{Rb}^{+}, \mathrm{Cs}^{+} ; \mathrm{M}=\mathrm{Fe}^{2+}, \mathrm{Co}^{2+}, \mathrm{Ni}^{2+}$ ) are presented. All eight new compounds are isostructural with the previously reported examples $\mathrm{NH}_{4} \mathrm{Li}_{3} \mathrm{Fe}\left(\mathrm{C}_{2} \mathrm{O}_{4}\right)_{3}$ and $\mathrm{KLi} \mathrm{i}_{3} \mathrm{Fe}\left(\mathrm{C}_{2} \mathrm{O}_{4}\right)_{3}$, crystallising in the rhombohedral space group $R \overline{3} c$, with $a \sim 11.3-11.6 \AA$, $c \sim 14.8-15.2 \AA$. In contrast to other families of "hybrid perovskites" such as the formates, these compounds can be regarded as closer structural relatives to inorganic (oxide) perovskites, in the sense that they contain direct linkages of the octahedral sites via bridging oxygen atoms (of the oxalate groups). It is of note, therefore, that monoatomic cations as large as $\mathrm{Cs}^{+}$can be incorporated into the perovskite-like $\mathrm{A}$ sites this structures type, which is not feasible in traditional $\mathrm{ABO}_{3}$ perovskites; indeed $\mathrm{CsLi}_{3} \mathrm{Ni}_{(}\left(\mathrm{C}_{2} \mathrm{O}_{4}\right)_{3}$ appears to exhibit the 'mostly tightly bound' 12 -coordinate $\mathrm{Cs}^{+}$ion in an oxide environment, according to a bond valence analysis.
\end{abstract}

\section{Introduction}

Perovskites (general formula $A B X_{3}$ ) have dominated the field of functional materials and exhibit a wide range of properties including superconductivity, ferroelectricity and magnetism. ${ }^{1}$ The introduction of organic components into the traditional perovskite structure could improve both the toxicity and sustainability of the compounds and introduce greater structural diversity. Hybrid perovskites, which may contain organic moieties at either the A, B or X sites, or further combinations of these, are already a highly-studied group of materials and there are many examples of such compounds with interesting properties. ${ }^{2,3}$ Examples of complex anions that may be incorporated the perovskite-like $\mathrm{X}$ site are cyanide, formate, azide, tetrahydroborate and hypophosphite. ${ }^{4-7}$ Whilst the oxalate ligand is already extensively used in coordination polymers, its ability to form perovskite-like structures has only recently been recognised in the composition $\mathrm{KLi}_{3} \mathrm{Fe}\left(\mathrm{C}_{2} \mathrm{O}_{4}\right)_{3} .{ }^{8}$ Here, we extend our studies of this unusual structure type by showing that substitution of $\mathrm{K}$ by $\mathrm{Rb}$ or $\mathrm{Cs}$ and of $\mathrm{Fe}$ by $\mathrm{Co}$ or $\mathrm{Ni}$ is feasible. Hence, eight new compositions, $\mathrm{A}^{\prime} \mathrm{Li}_{3} \mathrm{M}^{\prime \prime}\left(\mathrm{C}_{2} \mathrm{O}_{4}\right)_{3}\left(\mathrm{~A}=\mathrm{K}^{+}, \mathrm{Rb}^{+}, \mathrm{Cs}^{+} ; \mathrm{M}=\mathrm{Fe}^{2+}, \mathrm{Co}^{2+}, \mathrm{Ni}^{2+}\right)$, are reported and their structural variations are discussed.

\section{Experimental}

Crystalline samples were synthesised via a hydrothermal method from commercially available reagents. The reactions mixtures were heated between 160 and $220^{\circ} \mathrm{C}$ in a Teflon lined autoclave for 3 to 6 days. The resultant products were subsequently filtered and dried overnight at $50{ }^{\circ} \mathrm{C}$ prior to analysis by X-ray diffraction. Reactions typically produced a mixture of phases, and several variants of 
composition/temperature/solvent were explored to increase yield and purity. Further synthetic details are provide in ESI. Nevertheless, suitable single crystals could be isolated using an optical microscope and X-ray diffraction data were collected on a Rigaku SCXmini desktop instrument using Mo K $\alpha_{1}$ radiation $(\lambda=0.7107 \AA$ ) at $173 \mathrm{~K}$. The data were processed using Rigaku CrystalClear software and were solved and refined using the SHELX package within the WINGX program. ${ }^{9-11}$ Powder X-ray diffraction data were collected on a PANalytical Empyrean diffractometer using $\mathrm{Cu} K \alpha_{1}$ radiation $(\lambda=$ $1.5406 \AA$ ) at ambient temperature. The data were collected between $5-70^{\circ}$ for one hour, and subsequently analysed using the Rietveld method using GSAS and the Expgui interface. ${ }^{12,13}$ Magnetic data were collected on a quantum design MPMS SQUID instrument between $300 \mathrm{~K}$ and $2 \mathrm{~K}$. Data were collected at zero field and at $100 \mathrm{Oe}$ at $10 \mathrm{~K}$ intervals between 300 and $20 \mathrm{~K}$ and $2 \mathrm{~K}$ increments between $20 \mathrm{~K}$ and $2 \mathrm{~K}$. Samples initially underwent a zero field cool (ZFC) followed by a field heating/cooling cycle (FC).

\section{Results and discussion}

All eight new compositions crystallise in the same structure type, isotypic with $\mathrm{KLi}_{3} \mathrm{Fe}\left(\mathrm{C}_{2} \mathrm{O}_{4}\right)_{3},{ }_{3}$ in space group $R \overline{3} c$ (Table 1). In fact, the first compound reported with this structure type was $\mathrm{NH}_{4} \mathrm{Li}_{3} \mathrm{Fe}\left(\mathrm{C}_{2} \mathrm{O}_{4}\right)_{3},{ }^{14}$ but the relationship to the perovskite structure was not noted in that work. The direct relationship to the "cubic" $\mathrm{ABX}_{3}$ perovskite structure can be most clearly seen if the carbon atoms of the oxalate moiety are regarded as secondary features, both in the stoichiometry of the compound and in the corresponding structural description. Thus, Figure 1 shows the octahedral framework of an idealised cubic perovskite, compared to the corresponding framework in the perovzalate family. The stoichiometry of perovzalate may be written $\left[A^{\prime}(v a c)_{3}\right]_{A}\left[L_{3} M^{\prime \prime}\right]_{B}\left[C_{6} O_{12}\right]_{x}$ to emphasise the simultaneous 1:3 ordering of $A^{\prime} /$ vacancies at the $A$-site and $M^{\prime \prime} / L i$ at the $B$-site in an idealised " $\mathrm{A}_{4} \mathrm{~B}_{4} \mathrm{X}_{12}$ " quadruple perovskite. 
Table 1 Crystallographic data and refinement details

\begin{tabular}{|c|c|c|c|c|c|c|c|c|}
\hline Formula & $\mathrm{KLi}_{3} \mathrm{Co}\left(\mathrm{C}_{2} \mathrm{O}_{4}\right)_{3}$ & $\mathrm{KLi}_{3} \mathrm{Ni}\left(\mathrm{C}_{2} \mathrm{O}_{4}\right)_{3}$ & $\mathrm{RbLi}_{3} \mathrm{Fe}\left(\mathrm{C}_{2} \mathrm{O}_{4}\right)_{3}$ & $\mathrm{RbLi}_{3} \mathrm{Co}\left(\mathrm{C}_{2} \mathrm{O}_{4}\right)_{3}$ & $\mathrm{RbLi}_{3} \mathrm{Ni}\left(\mathrm{C}_{2} \mathrm{O}_{4}\right)_{3}$ & $\mathrm{CsLi}_{3} \mathrm{Fe}\left(\mathrm{C}_{2} \mathrm{O}_{4}\right)_{3}$ & $\mathrm{CsLi}_{3} \mathrm{Co}\left(\mathrm{C}_{2} \mathrm{O}_{4}\right)_{3}$ & $\mathrm{CsLi}_{3} \mathrm{Ni}\left(\mathrm{C}_{2} \mathrm{O}_{4}\right)_{3}$ \\
\hline Formula Weight & 382.91 & 382.69 & 426.20 & 429.28 & 429.06 & 473.64 & 476.72 & 476.50 \\
\hline Density $\left(\mathrm{g} \mathrm{cm}^{-3}\right)$ & 2.277 & 2.304 & 2.465 & 2.515 & 2.542 & 2.666 & 2.713 & 2.740 \\
\hline Crystal System & Trigonal & Trigonal & Trigonal & Trigonal & Trigonal & Trigonal & Trigonal & Trigonal \\
\hline Space Group & $R \overline{3} c$ & $R \overline{3} c$ & $R \overline{3} c$ & $R \overline{3} c$ & $R \overline{3} c$ & $R \overline{3} c$ & $R \overline{3} c$ & $R \overline{3} c$ \\
\hline$a / \AA$ & $11.3215(9)$ & $11.3071(8)$ & $11.4780(8)$ & $11.4019(8)$ & $11.3796(7)$ & $11.6046(8)$ & $11.5264(8)$ & $11.4908(8)$ \\
\hline$b / \AA$ & $11.3215(9)$ & $11.3071(8)$ & $11.4780(8)$ & $11.4019(8)$ & $11.3796(7)$ & $11.6046(8)$ & $11.5264(8)$ & $11.4908(8)$ \\
\hline$c / \AA$ & $15.0942(13)$ & $14.9434(12)$ & $15.1001(12)$ & $15.1029(12)$ & $14.9962(10)$ & $15.1779(12)$ & $15.2164(1)$ & $15.1534(10)$ \\
\hline$\alpha\left({ }^{\circ}\right)$ & 90 & 90 & 90 & 90 & 90 & 90 & 90 & 90 \\
\hline$\beta\left({ }^{\circ}\right)$ & 90 & 90 & 90 & 90 & 90 & 90 & 90 & 90 \\
\hline$\gamma\left({ }^{\circ}\right)$ & 120 & 120 & 120 & 120 & 120 & 120 & 120 & 120 \\
\hline$V / \AA^{3}$ & $1675.5(3)$ & $1654.6(3)$ & $1722.8(3)$ & $1700.4(3)$ & $1681.8(2)$ & $1770.1(3)$ & $1750.8(3)$ & $1732.8(3)$ \\
\hline Z & 6 & 6 & 6 & 6 & 6 & 6 & 6 & 6 \\
\hline Measured Ref & 5415 & 5246 & 5535 & 5449 & 5226 & 5297 & 5481 & 5412 \\
\hline \multirow{2}{*}{ Independent Ref } & $436[R($ int $)=$ & $426[R($ int $)=$ & $446[R($ int $)=$ & $444[R$ (int $)=$ & $441[R$ (int) $=$ & $447[R($ int $)=$ & $444[R($ int $)=$ & $442[R($ int $)=$ \\
\hline & $0.1083]$ & $0.0432]$ & $0.0542]$ & $0.0803]$ & 0.0747] & 0.0994] & 0.0439] & $0.0384]$ \\
\hline $\begin{array}{c}\text { Refined } \\
\text { Parameter }\end{array}$ & 37 & 37 & 37 & 37 & 37 & 37 & 37 & 27 \\
\hline GOOF & 0.631 & 0.711 & 0.815 & 0.610 & 0.876 & 1.145 & 0.853 & 0.935 \\
\hline $\begin{array}{l}\text { Final R Indices } \\
\qquad(I>2 \sigma(I))\end{array}$ & $\begin{aligned} R 1 & =0.0329, \\
w R 2 & =0.0808\end{aligned}$ & $\begin{aligned} R 1 & =0.0216, \\
w R 2 & =0.0748\end{aligned}$ & $\begin{aligned} R 1 & =0.0251, \\
w R 2 & =0.0886\end{aligned}$ & $\begin{array}{r}\mathrm{R} 1=0.0274 \\
\mathrm{wR} 2=0.0736\end{array}$ & $\begin{array}{r}R 1=0.0328, \\
w R 2=0.1025\end{array}$ & $\begin{array}{r}R 1=0.0346, \\
w R 2=0.1153\end{array}$ & $\begin{aligned} R 1 & =0.0202, \\
w R 2 & =0.0920\end{aligned}$ & $\begin{array}{r}R 1=0.0229, \\
w R 2=0.1012\end{array}$ \\
\hline
\end{tabular}



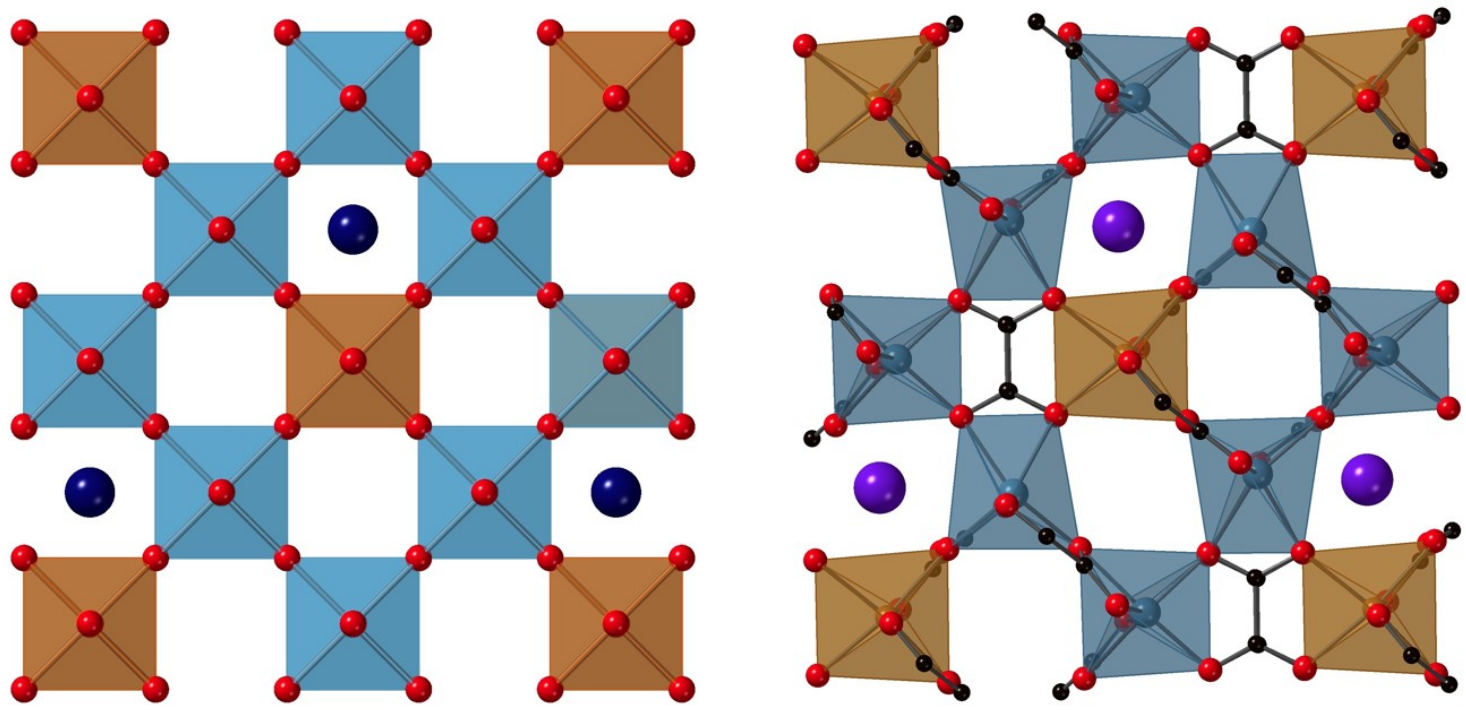

Figure 1. Hypothetical "cubic" perovskite structure incorporating simultaneous 1:3 cation ordering at both the $B$ and $A$ sites (left) and the corresponding observed perovzalate structure (right). $\mathrm{LiO}_{6}$ octahedral are shaded blue, $\mathrm{M}^{\prime \prime} \mathrm{O}_{6}$ octahedra brown and $\mathrm{A}^{\prime}$ cations purple. Note that there are direct B-O-B links mediated via the oxalate groups.

The particular arrangement of simultaneous 1:3 cation ordering at both the $A$ and $B$ perovskite sites has no precedent in traditional perovskite chemistry. ${ }^{15}$ The closest examples are the $\mathrm{CaCu}_{3} \mathrm{Ti}_{4} \mathrm{O}_{12}$ structure type, ${ }^{16}$ having 1:3 A-site ordering and derivatives such as $\mathrm{CaCu}_{3} \mathrm{Fe}_{2} \mathrm{Sb}_{2} \mathrm{O}_{12}$, which also has 1:1 B-site order. ${ }^{17}$ Further insight into the nature of this ordering pattern can be gleaned from examining the local coordination around each of the crystallographically-distinct A-sites. Figure 2 compares the generic cubic perovskite unit cell, with $\mathrm{A}$ at the body-centre position, $\mathrm{B}$ at the cell corners and $\mathrm{X}$ at each cell edge, with the corresponding pseudo-cubes in perovzalate. It can be seen that there are two distinct types of "cube" in perovzalate. In common with perovskite itself, both are surrounded by eight corner-shared $\mathrm{BO}_{6}$ octahedra, with two of the B-sites being occupied by $\mathrm{M}^{\prime \prime}$ (across a body-diagonal), but whereas those with $A^{\prime}$ at the centre have a fairly conventional environment, the ones with vacancies at the centre are "capped" across two opposite cube faces by oxalate moieties. This feature itself is obviously incompatible with occupancy of these particular cubes by any typical A-site cation, as it would lead to unfavourable $A$-carbon contacts. This drives the specific 1:3 ordering observed. The asymmetric unit contains one of each cation type, each on a special position in space group $R \overline{3} c$ (hexagonal setting) with Wyckoff positions/site symmetries: $A^{\prime}(6 b, \overline{3})$; $M^{\prime \prime}(6 a, 32)$; Li (18e, .2). Resulting bond lengths, angles and bond valence sums $(B V S)^{18}$ for each composition are given in Table 2. The local coordination environments around the $A^{\prime}$ and $M^{\prime \prime}$ sites are shown in Figure 3. 


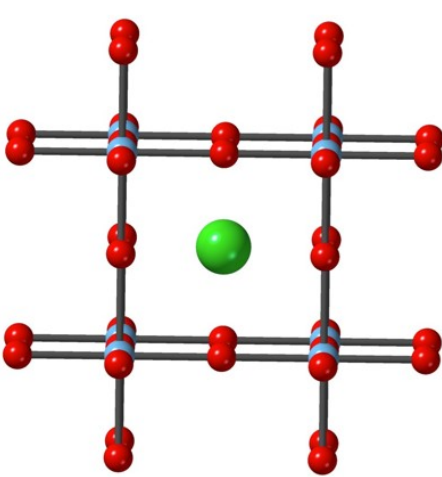

(a)

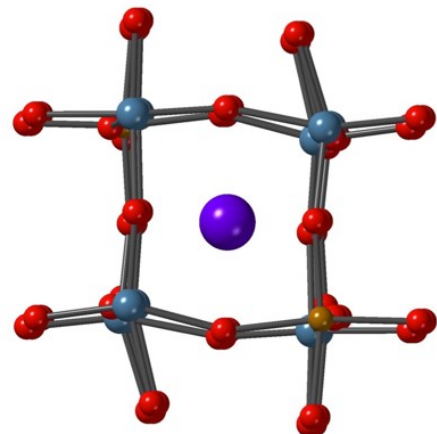

(b)

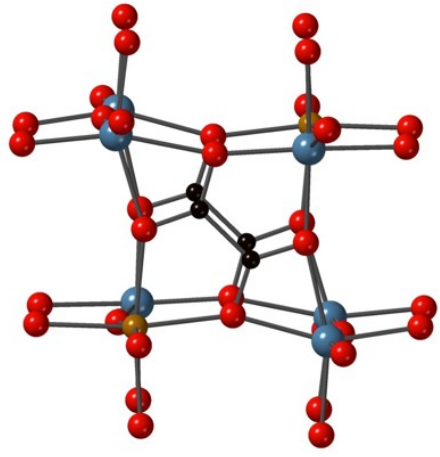

(c)

Figure 2. Comparison of perovskite $A$ sites (a) cubic $\mathrm{SrTiO}_{3}$, (b) $A$ site of $A^{\prime} \mathrm{Li}_{3} \mathrm{M}^{\prime \prime}\left(\mathrm{C}_{2} \mathrm{O}_{4}\right)_{3}$ and (c) vacant site of $\mathrm{A}^{\prime} \mathrm{Li}_{3} \mathrm{M}^{\prime \prime}\left(\mathrm{C}_{2} \mathrm{O}_{4}\right)_{3}$, trans-capped by oxalate groups.
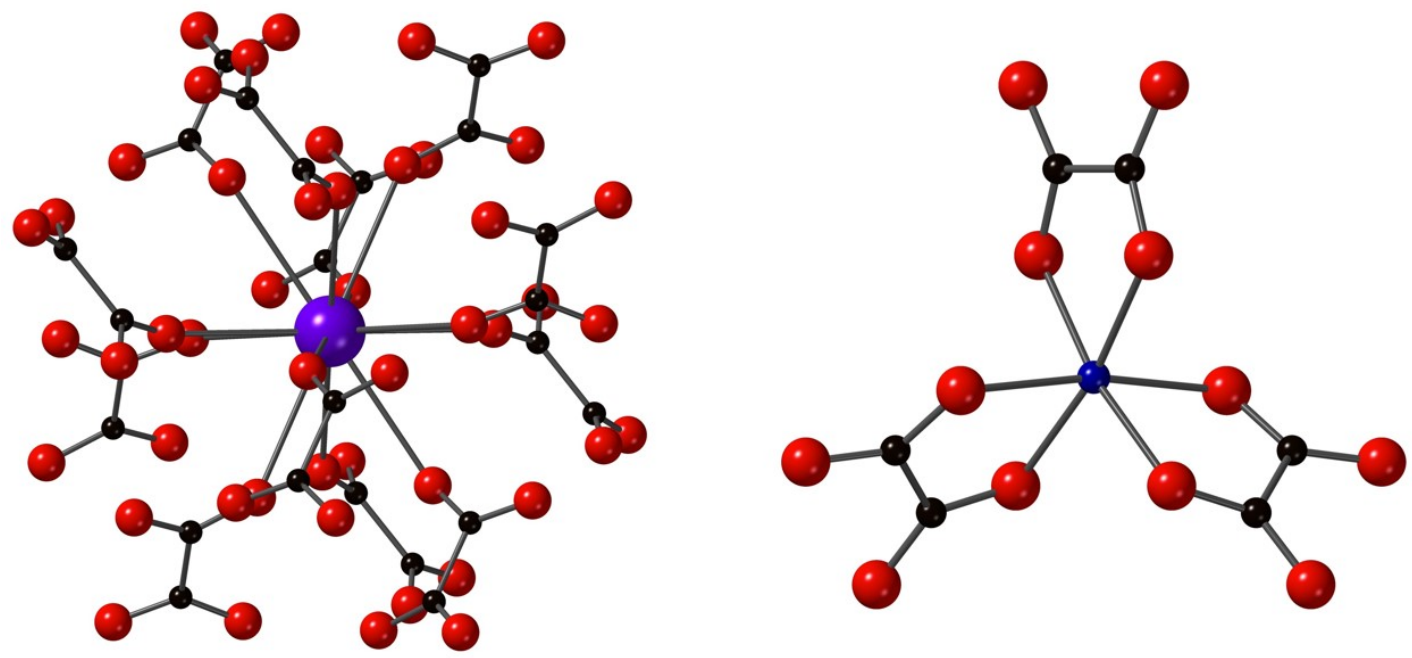

Figure 3. Local coordination environments of $A^{\prime}$ (left) and $M^{\prime \prime}$ (right) of perovzalate $A^{\prime} L_{3} M^{\prime \prime}\left(C_{2} O_{4}\right)_{3}$. $A^{\prime}$ cations are purple, $\mathrm{M}^{\prime \prime}$ cations blue, oxygen atoms red and carbon atoms black.

Naturally, as the absolute and relative sizes of the three cationic species varies, structural distortions are also influenced. The Li coordination environment, however, changes little across the series, and its bond valence is close to ideal. The varying size of the $\mathrm{M}^{\text {"l }}$ site results in systematically reduced 'bite' angles for the oxalate ligand versus increasing $M^{\prime \prime}$ size, for each series, $A^{\prime}=K, R b, C s$ (Figure 4). This results in more "distorted" $\mathrm{MO}_{6}$ octahedra, as quantified by a conventional distortion index, $\delta^{2}$, $\delta^{2}=\frac{1}{11} \sum\left(\theta_{i}-90\right)^{2}$ (Table 3 ), although the $\mathrm{LiO}_{6}$ octahedra are significantly more distorted in each case. The most dramatic, and perhaps surprising, structural effect, however, is in the nature of bonding at the $A^{\prime}$ sites. Taking each as 12 -coordinate, the bond valence sum at $A^{\prime}$ increases dramatically with ionic size, such that $\mathrm{Cs}^{+}$has BVS values far in excess of those normally observed. In each case, the mean Cs-O bond length is well below that found in the comprehensive study of Gagné ${ }^{19}$ (mean $\mathrm{Cs}^{\mathrm{xI}}-\mathrm{O}=3.377 \AA$ ). Gagné quotes a minimum mean bond length of $3.207 \AA$ for $\mathrm{Cs}^{\mathrm{xII}}-\mathrm{O}$ whereas the mean Cs-O bond length in $\mathrm{CsLi}_{3} \mathrm{Ni}_{(}\left(\mathrm{C}_{2} \mathrm{O}_{4}\right)_{3}$ is only $3.155 \AA$, and the corresponding BVS of $\mathrm{Cs}$ in $\mathrm{CsLi}_{3} \mathrm{Ni}\left(\mathrm{C}_{2} \mathrm{O}_{4}\right)_{3}$ is 1.44 valence units (v.u.) using Gagné's revised bond valence parameters for $\mathrm{Cs}^{\mathrm{x}}-\mathrm{O}^{19}$, and as high as 1.64 v.u. using Brese's parameters ${ }^{18}$. Indeed Gagné's full list of compounds containing $\mathrm{CsO}_{12}$ polyhedra contains only five compounds with their six shortest $\mathrm{Cs}-\mathrm{O}$ bond of the order of $\sim 3.12$ 
$\AA$ or lower. Most of these have their next six Cs-O bonds considerably longer. Of note are the compounds $\mathrm{Cs}_{2} \mathrm{PbCu}\left(\mathrm{NO}_{2}\right)_{6}{ }^{20}$ and $\mathrm{CsNa}_{3} \mathrm{Li}_{12}\left(\mathrm{GeO}_{4}\right)_{4},{ }^{21}$ which appear to have the highest $\mathrm{BVS}$ for $\mathrm{CsO}_{12}$ environments amongst previously reported, well-determined structures: viz., 1.32 and 1.35 v.u., respectively, using Gagné's BV parameters. Other Cs oxalates, for example $\mathrm{CsHC}_{2} \mathrm{O}_{4}{ }^{22}$ (BVS for $\mathrm{Cs}^{\mathrm{XII}}-\mathrm{O}$ $=1.13$ v.u.), do not show such extreme over-bonding of Cs. A fuller list of calculated Cs BVS values from Gagné's list is provided in ESI.

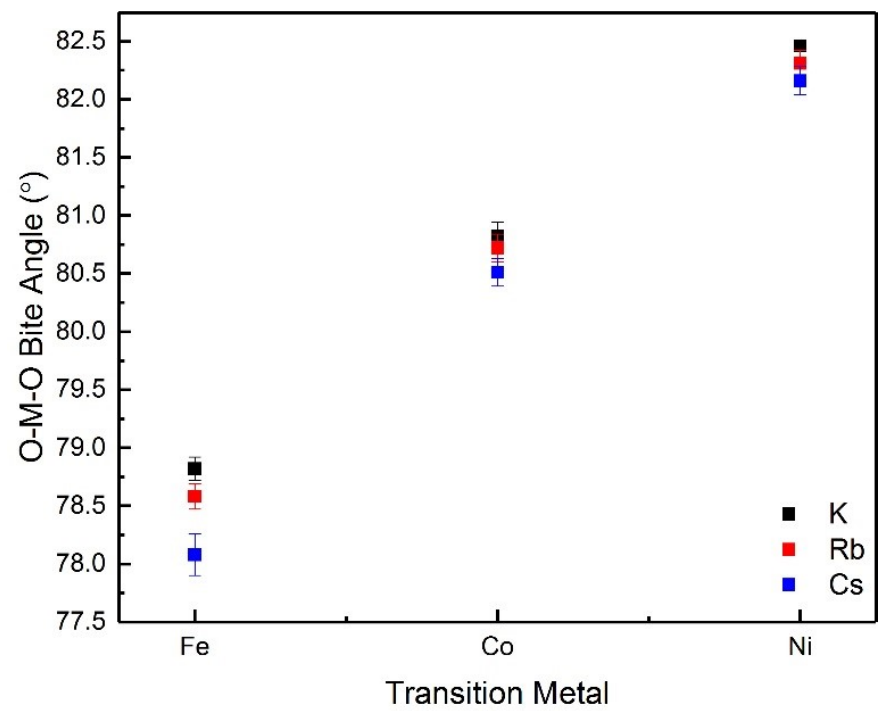

Figure 4. Variation of O-M-O bite angles $\left({ }^{\circ}\right)$ of perovzalates $\left(A^{\prime} \mathrm{Li}_{3} \mathrm{M}^{\prime \prime}\left(\mathrm{C}_{2} \mathrm{O}_{4}\right)_{3}\right)$ with $\mathrm{A}^{\prime}$ and $\mathrm{M}^{\prime \prime}$ cations

Table 3. Distortion parameters, $\delta^{2}$, for the $L i$ and $M$ sites in $\left(A^{\prime} L_{3} M^{\prime \prime}\left(C_{2} O_{4}\right)_{3}\right)$

\begin{tabular}{ccccc}
\hline Alkali Metal & & $\mathrm{ALi}_{3} \mathrm{Fe}\left(\mathrm{C}_{2} \mathrm{O}_{4}\right)_{3}$ & $\mathrm{ALi}_{3} \mathrm{Co}\left(\mathrm{C}_{2} \mathrm{O}_{4}\right)_{3}$ & $\mathrm{ALi}{ }_{3} \mathrm{Ni}\left(\mathrm{C}_{2} \mathrm{O}_{4}\right)_{3}$ \\
\hline \multirow{2}{*}{$\mathrm{K}$} & $\mathrm{M}^{\prime \prime}$ & 47.94 & 32.63 & 21.24 \\
& $\mathrm{Li}$ & 196.8 & 195.1 & 194.1 \\
& & & & \\
Rb & $\mathrm{M}^{\prime \prime}$ & 49.44 & 32.64 & 22.16 \\
& $\mathrm{Li}$ & 206.1 & 202.2 & 202.4 \\
& & & & \\
\multirow{2}{*}{$\mathrm{Cs}$} & $\mathrm{M}^{\prime \prime}$ & 54.41 & 33.99 & 23.83 \\
& $\mathrm{Li}$ & 222.7 & 218.3 & 218.0 \\
\hline
\end{tabular}

An additional measure of the bonding at the $A$ and $B$ sites in perovskites is the tolerance factor $(t)$. These are shown for the present family in Table 4 (calculated using Shannon's ionic radii ${ }^{23}$ for 12 ccordinate $\mathrm{A}^{\prime}$ and 6-coordinate $\left.\mathrm{Li}, \mathrm{M}^{\prime \prime}, \mathrm{O}^{2-}\right)$. As can be seen, the potassium-containing members of this family fall within the reasonably allowed tolerance factor limits seen in conventional oxides perovskites, whereas the $\mathrm{Rb}$ and $\mathrm{Cs}$ derivatives lie well above the ideal value of $t=1$. In the case of conventional oxide perovskites the "cubic" perovskite structure would be unstable for such high $t$ values, and preferential formation of a hexagonal perovskite or other structure type would occur. Apparently in this family the perovskite-like octahedral framework is further stabilised by the additional influence of the bridging oxalate moieties, despite the compressive strain at the large Asite cations. We note that there are no examples of significant $\mathrm{Rb}$ or $\mathrm{Cs}$ incorporation into cubic $\mathrm{ABO}_{3}$ perovskites, whereas such structures do exist for the corresponding fluorides, where the divalent (i.e. relatively large) cation on the $\mathrm{B}$-site permits the incorporation of a larger A-site cation. Thus, $\mathrm{CsCaF}_{3}(t$ $=0.98)$ adopts the cubic perovskite structure, whereas $\mathrm{CsNiF}_{3}(t=1.13)$ adopts a hexagonal $(2 \mathrm{H})$ 
perovskite structure. $\mathrm{Cs}^{+}$represents the largest available monatomic cation. In order to "push" the geometric limits of the present structure type we attempted reactions aimed at preparing analogues with larger (e.g. methylammonium) or smaller $\left(\mathrm{Na}^{+}\right)$cations at the A-site. So far, this has been unsuccessful, suggesting a stability region incorporating only $\mathrm{K}, \mathrm{Rb}$ or $\mathrm{Cs}$ at the $\mathrm{A}$-site in the perovzalate family.

Table 4. Tolerance factors of the perovzalate compounds $\left(\mathrm{A}^{\prime} \mathrm{Li}_{3} \mathrm{M}^{\prime \prime}\left(\mathrm{C}_{2} \mathrm{O}_{4}\right)_{3}\right)$

\begin{tabular}{cccc}
\hline Alkali Metal & $\mathrm{ALi}_{3} \mathrm{Fe}_{\left(\mathrm{C}_{2} \mathrm{O}_{4}\right)_{3}}$ & $\mathrm{ALi}_{3} \mathrm{Co}\left(\mathrm{C}_{2} \mathrm{O}_{4}\right)_{3}$ & $\mathrm{ALi}_{3} \mathrm{Ni}\left(\mathrm{C}_{2} \mathrm{O}_{4}\right)_{3}$ \\
\hline $\mathrm{K}$ & 1.000 & 1.004 & 1.010 \\
$\mathrm{Rb}$ & 1.026 & 1.031 & 1.037 \\
$\mathrm{Cs}$ & 1.080 & 1.084 & 1.091 \\
\hline
\end{tabular}

Preliminary magnetic measurements were carried out on several samples that exhibited good phase purity. The $1 / \chi$ versus $T$ data for two samples are shown in Figure 5 , with a linear Curie-Weiss fit in the region $150-300 \mathrm{~K}$. Both samples show no evidence of magnetic ordering down to $2 \mathrm{~K}$, perhaps not surprising for such magnetically-dilute systems. Derived parameters for $\mathrm{KLi}_{3} \mathrm{Co}\left(\mathrm{C}_{2} \mathrm{O}_{4}\right)_{3}$ and $\mathrm{KLi}{ }_{3} \mathrm{Ni}\left(\mathrm{C}_{2} \mathrm{O}_{4}\right)_{3}$, respectively are $\theta=-2.00 \mathrm{~K},-25.0 \mathrm{~K} ; \mathrm{C}=2.899 \mathrm{~cm}^{3} \mathrm{~mol}^{-1}, \mathrm{C}=1.635 \mathrm{~cm}^{3} \mathrm{~mol}^{-1} ; \mu_{\text {eff }}=4.815$ $\mu_{\mathrm{B}}, 3.62 \mu_{\mathrm{B}}$, both of which are within the expected range for the high-spin divalent cations. ${ }^{24}$
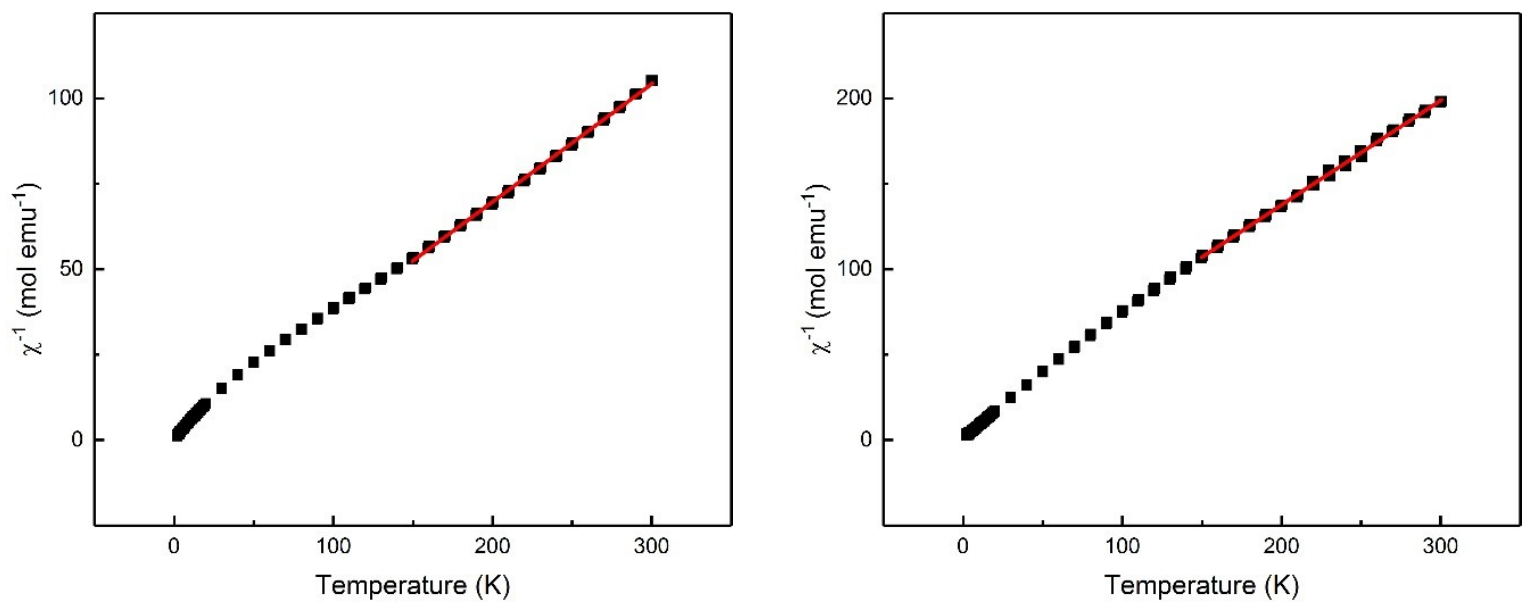

Figure 5. Magnetisation data $(1 / \chi$ versus $\mathrm{T})$ for (left) $\mathrm{KLi}_{3} \mathrm{Co}\left(\mathrm{C}_{2} \mathrm{O}_{4}\right)_{3}$ and (right) $\mathrm{KLi} 3 \mathrm{Ni}\left(\mathrm{C}_{2} \mathrm{O}_{4}\right)_{3}$ 
Table 2 Bond lengths $(\AA)$ and bond valence sums (valence units) ${ }^{18}$ derived from single crystal data collected at $173 \mathrm{~K}$

\begin{tabular}{|c|c|c|c|c|c|c|c|c|}
\hline & $\mathrm{KLi}_{3} \mathrm{Co}\left(\mathrm{C}_{2} \mathrm{O}_{4}\right)_{3}$ & $\mathrm{KLi}_{3} \mathrm{Ni}\left(\mathrm{C}_{2} \mathrm{O}_{4}\right)_{3}$ & $\mathrm{RbLi}_{3} \mathrm{Fe}\left(\mathrm{C}_{2} \mathrm{O}_{4}\right)_{3}$ & $\mathrm{RbLi}_{3} \mathrm{Co}\left(\mathrm{C}_{2} \mathrm{O}_{4}\right)_{3}$ & $\mathrm{RbLi}_{3} \mathrm{Ni}\left(\mathrm{C}_{2} \mathrm{O}_{4}\right)_{3}$ & $\mathrm{CsLi}_{3} \mathrm{Fe}\left(\mathrm{C}_{2} \mathrm{O}_{4}\right)_{3}$ & $\mathrm{CsLi}_{3} \mathrm{Co}\left(\mathrm{C}_{2} \mathrm{O}_{4}\right)_{3}$ & $\mathrm{CsLi}_{3} \mathrm{Ni}\left(\mathrm{C}_{2} \mathrm{O}_{4}\right)_{3}$ \\
\hline \multirow[t]{3}{*}{ Li-O } & $2.019(6) \times 2$ & $2.020(3) \times 2$ & $2.024(6) \times 2$ & $2.029(7) \times 2$ & $2.023(6) \times 2$ & $2.032(7) \times 2$ & $2.038(5) \times 2$ & $2.042(5) \times 2$ \\
\hline & $2.130(3) \times 2$ & $2.1344(14) \times 2$ & $2.138(3) \times 2$ & $2.147(3) \times 2$ & $2.161(3) \times 2$ & $2.177(4) \times 2$ & $2.185(3) \times 2$ & $2.197(3) \times 2$ \\
\hline & $2.165(6) \times 2$ & $2.152(3) \times 2$ & $2.196(6) \times 2$ & $2.178(6) \times 2$ & $2.174(5) \times 2$ & $2.230(7) \times 2$ & $2.215(5) \times 2$ & $2.203(5) \times 2$ \\
\hline BVS & 1.08 & 1.09 & 1.05 & 1.05 & 1.04 & 0.98 & 0.98 & 0.97 \\
\hline M-O & $2.083(2) \times 6$ & $2.0523(10) \times 6$ & $2.127(2) \times 6$ & $2.089(2) \times 6$ & $2.053(2) \times 6$ & $2.132(3) \times 6$ & $2.095(2) \times 6$ & $2.059(2) \times 6$ \\
\hline BVS & 2.09 & 2.16 & 2.07 & 2.05 & 2.16 & 2.05 & 2.02 & 2.13 \\
\hline \multirow[t]{2}{*}{ K-O } & $3.007(2) \times 6$ & $3.0179(9) \times 6$ & $3.057(2) \times 6$ & $3.048(2) \times 6$ & $3.0560(17) \times 6$ & $3.1228(19) \times 6$ & $3.1199(15) \times 6$ & $3.1240(17) \times 6$ \\
\hline & $3.152(2) \times 6$ & $3.1215(11) \times 6$ & $3.193(2) \times 6$ & $3.164(2) \times 6$ & $3.139(2) \times 6$ & $3.234(4) \times 6$ & $3.207(2) \times 6$ & $3.186(2) \times 6$ \\
\hline BVS & 0.94 & 0.96 & 1.19 & 1.24 & 1.27 & 1.55 & 1.61 & 1.64 \\
\hline
\end{tabular}




\section{Conclusions}

We have presented a family of hybrid perovskite-related oxalates ("Perovzalates") of general composition $\mathrm{A}^{\prime} \mathrm{Li}_{3} \mathrm{M}^{\prime \prime}\left(\mathrm{C}_{2} \mathrm{O}_{4}\right)_{3}\left(\mathrm{~A}=\mathrm{K}^{+}, \mathrm{Rb}^{+}, \mathrm{Cs}^{+} ; \mathrm{M}=\mathrm{Fe}^{2+}, \mathrm{Co}^{2+}, \mathrm{Ni}^{2+}\right)$. All compounds are isostructural, with rhomobohedral symmetry, and can be regarded as derived from the traditional oxide perovskite structure, $\mathrm{ABO}_{3}$, by replacement of oxide ligands by oxalate groups with concomitant ordering of $\mathrm{K}^{+} /$vacancies at the $\mathrm{A}$ site and $\mathrm{Li} / \mathrm{M}^{\prime \prime}$ at the B-site. The ordering correlates with accommodation of the oxalate groups, which effectively "cap" the opposite faces of unoccupied A-site cubes. A particularly unusual feature of this family is that cations as large as $\mathrm{Cs}^{+}$can be accommodated at the perovskitelike A-site; a phenomenon which has not been seen in traditional oxide perovskites. In fact, existing data suggest that $\mathrm{CsLi}{ }_{3} \mathrm{Ni}\left(\mathrm{C}_{2} \mathrm{O}_{4}\right)_{3}$ sets a "world record" for the most tightly bound 12-coordinate caesium atom in an oxide environment.

\section{Acknowledgements}

We would like to thank the University of St Andrews, and the EPSRC (doctoral studentship to RC: DTG012 EP/K503162-1) for funding.

Supporting information: synthesis details, powder XRD data and bond valence analyses.

Single crystal X-ray diffraction data for all refinements have been deposited: CDS deposition numbers 1944088-1944095

The research data pertaining to this paper are available at

https://doi.org/10.17630/74dd1b0a-1ed2-4d93-aeb0-128182fe7bed

\section{References}

1 J. P. Attfield, P. Lightfoot and R. E. Morris, Dalton Trans., 2015, 44, 10541-10542.

2 B. Saparov and D. B. Mitzi, Chem. Rev., 2016, 116, 4558-4596.

3 P. Jain, V. Ramachandran, R. J. Clark, D. Z. Hai, B. H. Toby, N. S. Dalal, H. W. Kroto and

A. K. Cheetham, J. Am. Chem. Soc., 2009, 131, 13625-13627.

4 G. Kieslich and A. L. Goodwin, Mater. Horizons, 2017, 4, 362-366.

$5 \quad$ X. Y. Wang, L. Gan, S. W. Zhang and S. Gao, Inorg. Chem., 2004, 43, 4615-4625.

6 M. Trzebiatowska, M. Maczka, M. Ptak, L. Giriunas, S. Balciunas, M. Simenas, D. Klose and J. Banys, J. Phys. Chem. C, 2019, 123, 11840-11849.

7 Y. Wu, T. Binford, J. A. Hill, S. Shaker, J. Wang and A. K. Cheetham, Chem. Commun., 2018, 54, 3751-3754.

8 W. Yao, Y.Y. Guo and P. Lightfoot, Dalton Trans., 2017, 46, 13349-13351.

9 Rigaku, CrystalClear. Rigaku Corporation, Tokyo, Japan, 2014.

10 G. M. Sheldrick, Acta Crystallogr. Sect. C Struct. Chem., 2015, 71, 3-8.

11 L. J. Farrugia, J. Appl. Crystallogr., 2012, 45, 849-854.

12 A. C. Larson and R. B. Von Dreele, General Structure Analysis System (GSAS), 2004.

13 B. H. Toby, J. Appl. Crystallogr., 2012, 34, 210-213.

14 J. H. Li, H. Liu, L. Wei and G. M. Wang, Solid State Sci., 2015, 48, 225-229.

15 M. V. Talanov, Acta Crystallogr. Sect. A, 2019, 75, 379-397. 
16 A. Deschanvres, B. Raveau and F. Tollemer, Bull. Chim. Soc. Fr, 1967, 11, 4077-4078.

17 W. T. Chen, M. Mizumaki, T. Saito and Y. Shimakawa, Dalt. Trans., 2013, 42, 1011610120.

18 N. E. Brese and M. O'Keeffe, Acta Crystallogr. Sect. B, 1991, 47, 192-197.

19 O. C. Gagné and F. C. Hawthorne, Acta Crystallogr. Sect. B Struct. Sci. Cryst. Eng. Mater., 2016, 72, 602-625.

20 H. Ahsbahs, H. Sowa and E. Hellner, Fortschritte der Mineral. Beih., 1982, 60, 35-36.

21 R. Brandes and R. Hoppe, Z. anorg. allg. Chem., 1995, 621, 713-718.

22 L. N. Kholodkovskaya, V. K. Trunov and N. B. Tskhelashvili, J. Struct. Chem., 1990, 31, 667-670.

23 R. D. Shannon, Acta Crystallogr. Sect. A, 1976, 32, 751-767.

24 F. A. Cotton and G. Wilkinson, Advanced Inorganic Chemistry: A Comprehensive Text, John Wiley \& Sons Ltd., New York, 4th edn., 1980. 